\title{
SELECTED PROBLEMS OF OCCUPATIONAL STRESS IN THE ORGANIZATION
}

\author{
KAROLINA DRELA \\ University of Szczecin, Faculty of Management and Economics of Services, POLAND \\ e-mail: karolina.drela@wzieu.pl
}

\begin{tabular}{l|c} 
RECEIVED & 6 November 2018 \\
ACCEPTED & 3 December 2018 \\
JEL & \\
CLASSIFICATION & J2, J5, J8, M5
\end{tabular}

KEYWORDS stress, organisation, work, occupational stress, labour market

ABSTRACT The aim of the deliberations in this article is presentation of chosen issues associated with occupational stress in the organisation. A hypothesis was put forward: occupational stress becomes a regular phenomenon and reaches excessive levels, affect the performance of the employee, his/her satisfaction and well-being, as well as lower the involvement of employees and, consequently, force them to resign from work. In the beginning deliberations concerning stress definition. Then occupational stress and types of stress in the workplace were presented. For a better illustration the most important factors affecting occupational stress were shown. The subject matter of a successive part was the causes and symptoms of stress at work in the organisation and to the types of stressors. The final part deals with more important conclusions of the deliberations.

\section{Introduction}

A lot of people are inclined to believe that stress is a phenomenon typical of the 20th and 21st centuries, however it has accompanied each living organism from the beginning of the existence, starting with the birth of life on Earth. Therefore, it should be noted that stress contributes to all events, regardless of age, sex, religion, political beliefs. One cannot completely get rid of it, nor accept it, it is an inseparable element of the human condition. It is 
created by every new situation or every new task - stress accompanies the human being in every action, including professional life. Hence the subject of particular interest within this article is the issue related to the problem of occupational stress in the organisation. Therefore an attempt was undertaken to present the issues related to stress, workplace stress and occupational burnout, paying particular attention to the causes and symptoms of stress at work in the organisation and to the types of stressors. Characteristics of the most important stressors related to work in the organization were also made.

\section{Stress and its types}

When defining the word stress, it must be mentioned that it comes, among others, from the Latin past participle strictus, from the verb stringere (squeeze, tighten) and from the word districtus, the past participle of the verb distringere (hinder) (The American Heritage Dictionary of the English Language, 2016). In this way formerly difficulties or suffering or even disease were defined. In general, this is a group of specific and nonspecific responses of the organism to stimulus events, interfering the balance and exposing to a trial or exceeding the ability to cope. According to The dictionary of foreign words and phrases (Kopaliński, 1971): stress is a physical, chemical and emotional factor (an injury, an allergen or fear), to which the organism is not able to sufficiently adapt and which causes physiological tension that may be beneficial for the organism and can contribute to the outbreak of a disease. However, according to the Encyclopedia of PWN (PWN, 2018) in psychology stress is treated as the load state of the mental adjustment system resulting in a situation of "danger, difficulty or inability to implement purposes, tasks, values important to the individual". According to the PWN Dictionary of the Polish language (PWN, 2018a) stress is considered "the state of increased nervous tension, as a reaction to negative physical or mental stimuli".

The research on stress was developed in the 30s of the 20th century. Hans Selye (1960) in 1936 introduced the theory of stress, regarding it as a biological phenomenon which causes the way (non-specific) of the reaction of the organism to any requirements (physical, mental or somatic) given to it. Prolonged stress, which leads to the destruction is called distress, and the physical and emotional exhaustion combined with a feeling of frustration, powerlessness and apathy - is the syndrome of burnout. It is the result of negative stress, which one experiences at work. But stress also has positive sides. It results in the mobilisation of the whole organism, to get out of a difficult situation. It is a positive stress called eustress. The response to stress can help an individual, for example, get out of a variety of oppression or even save one's life. Positive stress can motivate and encourage people to act, but it should be kept in mind that the boundary between positive and negative stress is very individual and depends on the features of character, personality, often on experiences and the contemporary life situation of the person. Negative effects of stress should be fought off. There are different and individual ways to deal with stress, but it is most important to learn about the sources of stress, and how a human being reacts to stressful situations.

The fact that certain kind of stress is beneficial and another one is harmful, does not depend on the type or intensity of the stressor, but on the response to the event or situation. Therefore, one can distinguish different types of stress, presented in Table 1. 
Table 1. Types of stress

\begin{tabular}{ll}
\hline $\begin{array}{l}\text { Biological stress: according to Seley it is a reaction of the organism } \\
\text { to any requirement it faces from the outside, and the harmful factors } \\
\text { affect the organism through the skin and mouth and nasal ducts; } \\
\text { the pain is a symptom of biological stress }\end{array}$ & $\begin{array}{l}\text { Psychological stress: is the result of a specific situation, which threatens } \\
\text { the stability and the mental balance of the individual, compelling } \\
\text { to change behaviour in order to adapt to a given situation or to oppose it }\end{array}$ \\
\hline $\begin{array}{ll}\text { Emotional stress: is the result of the collision of the processes related } \\
\text { to excessive stimulation and inhibition and the overloading of the nervous } \\
\text { system by too strong stimuli; it is difficult to be mastered, as it prevents } \\
\text { the fulfilment of the revealed needs and leads to frustration }\end{array}$ & $\begin{array}{l}\text { Moral stress (the so-called psychosocial stress): it depends on the } \\
\text { structure of social life and is related to the assessment of human } \\
\text { behaviour in the ethical aspect; man in life is guided by specific ethical } \\
\text { norms and commonly accepted values in society }\end{array}$ \\
$\begin{array}{ll}\text { Chronic stress (negative, distress): negative and long-lasting stress that } \\
\text { and may lead to psychosomatic diseases }\end{array}$ & $\begin{array}{l}\text { Short-term stress (positive, eustress): called good stress: it is light and } \\
\text { pleasant, associated with the indispensable level of stimulating the needs } \\
\text { of a healthy organism to act }\end{array}$ \\
\hline
\end{tabular}

Source: the author's own description based Selye (1977), p. 25; Grochmal (1992).

A definition of occupational stress was presented by Richard Lazarus (1986, pp. 1-39), who noticed that "stress is a special relationship between a person and the environment which is assessed by the person as straining his/her resources and threatening his/her wellbeing". The presented definition reflects the relationship between the employee and the environment (Widerszal-Bazyl, 2002, chapter 5).

\section{Occupational stress}

Stress in the workplace occurs when working people feel psychic discomfort concerning the conditions or requirements of work exceeding their capabilities. Stress at work is most often defined as a pathogenic physical and emotional reaction of the organism to requirements and conditions that do not coincide with the abilities, resources or needs of the employee. The presented definition places the causes of stress in both the sick working environment and in the employee himself/herself.

At the moment when the causes of stress are located in the work environment, the following definition can be adopted: stress at work means the conditions and requirements in the workplace that damage both the social, mental and physical functioning of the employee. Special attention should be paid to the sick environment of work. Problems with correct assessment of the risks associated with stress are most often a source of difficulty in measuring stress, which cannot be measured with such ease as the levels of other harmful factors in the work environment are measured. General knowledge about the phenomenon of stress also turns out to be insufficient to cope with the estimation of occupational risk in this area.

In the workplace three types of stress are usually experienced:

a) short-term stress, which is a typical phenomenon characteristic of the functioning in the organisation; it is associated with situations not exceeding adaptability possibilities of an individual; it motivates to action as well as to undertake activities, and it also makes the employee more focus on the task; however, if the stress lasts long, it leads to occupational burnout and also to loss of health, for example depression;

b) chronic stress - associated with often repeated difficulties, gradually destroying the organism and psyche of the employee;

c) traumatic stress, which is a consequence of certain exceptional situations that may be associated with risks and injuries (an accident at work resulting in death or bodily injury). 
Stress is most often understood as a state of nervous tension, which is sometimes a reaction to the action of negative psychic or possibly physical stimuli. This definition does not allow in any way capturing the problem as a threat within the meaning of the health and safety rules at work, as it does not include general factors and phenomena accompanying environmental impact of the energy that destroys the workers, the environment or property. The full description of any threat, including stress, is associated with the recognition of (Kędzia, Kowalewski, 2002, p. 46):

- threatening factors, that is all carriers (objects, people, processes, phenomena) that potentially have the so-called destructive energy (energy that exceeds the threshold of resistance of the victim),

- the emergency situation (the impact of destructive energy) - the circumstances where people, environment or property are exposed to threatening factors,

- a harmful event (forms of impact of destructive energy), i.e. an event in which situations of a threat change into damage.

Therefore, the analysis of stress requires the understanding of how and in what conditions stress acts and appears; it requires also the determination of what factors in the work environment are conducive to the occurrence of stress as well as how it may affect workers, employers and society.

\section{The causes and symptoms of stress at work in the opyanisation}

When the requirements in the work environment for individuals are adapted to physical or psychological abilities, the employee has appropriate knowledge or skills and can be helped by others, then difficulties at work are resolved and stress subsides. After the period of rest it is possible to take another activity. Coping with inconvenient situations results in success. Self-satisfaction appears, as well as satisfaction with work, with superiors or colleagues. People learn, e.g. a modern way of coping with difficult situations by increasing knowledge, skills, and work experience. This type of stress strengthens the employee's sense of values, of learning and doing new things, encourages changes and is profitable for both the employee and the employer or for the whole enterprise.

There are also situations in which requirements appear too often, last long and are so large that they exceed the capabilities of the employee or the individual does not have proper knowledge, skills or support of other people, needed to deal with them - crises situations are not solved and the stressful response still continues. The employee is in a state of permanent agitation, tension, activation of all internal systems of the organism. Depending on the causes of stress and situations in which a person is found, he/she can also experience all sorts of uncomfortable feelings, such as fear, anxiety, anger. If such tension persists for a longer time, the employee may lose strength and start to feel fatigue and musculo-skeletal disorders. Instead of being active, prolonged stress encourages saving energy. The person is unwilling to act, unfavourable to additional duties at work and to any changes. A further consequence of stress can also be a feeling of helplessness and guilt, apathy, sadness, loss of self-confidence, and in the end also a loss of confidence in superiors and co-workers as well as the loss of confidence in the enterprise - when the situation in the workplace is not improved. This type of stress understates the awareness of their own values, temporarily also reduces the ability to cope with difficult or new tasks at work - it is unfriendly, both for the employee, the employer and the whole enterprise. The return to the full professional activity is likely after a period of rest as well as the regeneration of the organism. The following activities can also be required: partial changes in the way of work, slow and gradual adjustment to professional duties, understanding from the side of colleagues or additional assistance of supervisors, co-workers, managers, family or specialists. 
For the emergence of harmful effects of stress, factors transforming themselves to stressors such as the level of requirements and the capacity to meet these demands have a critical meaning. The level of support possible to obtain from the outside also affects the possibility of dealing with stress, in a situation where the level of requirements exceeds the capabilities of the individual. Therefore, for the purposes of the analysis of occupational stress, the three-factor concept of Robert Karaska and Tore Theorell (1990) is useful, in which occupational stress is the result of the interaction of the level of work requirements, as well as the level of control over work and the level of social support in the workplace. This model assumes that the greatest level of occupational stress occurs when an employee under a small real effect on work must meet high demands, not having at the same time favorable support from the organisation. Empirical studies, in which this model was used, allowed fairly commonly determining the relationship between the requirements, control and support, and the level of occupational stress and health of workers (Cieślak, Widerszal-Bazyl, 2000). Thus factors threatening employees can be both high requirements that are related to work and the insufficient level of control over the work (resulting from the style of management or work organisation), as well as the lack of social support in the workplace and in the work environment.

The threatening factors in the area of the requirements are, inter alia (Orlak, 2008, p. 46):

- quantitative work overload, appearing as a result of such threatening situations as, for example, an excessive amount of tasks - surpassing norms of working time, uneven pace of work,

- sudden and considerable amount of work, imposed too big pace of work, work under pressure and in a hurry, frequent and significant physical activity, frequent changes at work (the need for parallel execution of a large number of different tasks),

- qualitative work overload caused, among others, by: difficult or mentally complex tasks requiring: permanent improvement of skills, being creative, responsibility for finances and for people, maintaining constant vigilance and suppressing one's own needs or reactions (e.g. suppression of emotion or overcoming fatigue while working at night), serious consequences of error, moral dilemmas at work,

- quality underload, which may be the result of, among others: monotony and monotype of work or work below the capabilities of the individual,

- conflictual character of the role affecting the human being: for example: in the case of the need for cooperation with others, the need to reconcile the conflicting interests, in the situation of receiving conflicting commands, continuous availability,

- the physical working conditions causing stress resulting from the following situations: the need to work in dirt or odour, the possibility of getting infected with a disease, the noise, considerable and frequent differences in temperature or pressure, work in winter, travel requiring frequent changes of time zones, work without natural light, etc.

Threatening situations in the area of control over work include, for example: the lack of clarity as to the purpose of work and the requirements, as to the scope of duties or responsibility, as to the working methods (e.g. the lack of training); the lack of clarity in terms of criteria for the assessment of work or the lack of the reverse information on the results of the work; the lack of the effect on the work plan (including the plan of results); the lack of possibilities to decide about time and the way of performing a task; a low sense of security at work.

Threats in terms of social support in the work environment refer to the lack of the real possibility of obtaining various forms of help from co-workers and supervisors. As examples of situations that threaten in this area the following ones can be mentioned: work in isolation; a limited contact with the superior; the lack of an incentive 
system in the enterprise or a motivation system oriented towards competition or a discretionary incentive system (the lack of clear criteria for the bonus system and promotion); the lack of means or tools needed to work; the lack of information needed for work and changes in the enterprise; an authoritarian style of management; the lack of respect for the private life of the employee (e.g. an unjustified request of availability); psychological or physical violence in the workplace.

In the literature, one can also find various classifications of stressors at work. For example, Carry Cooper and Judi Marshall mention six categories of factors (1987, pp. 123-164):

- work-related, e.g. work-overload or work-underload, inadequate working conditions, shift work, time pressures, material properties of the working environment,

- related to the roles played in the organisation, including conflict of roles or role ambiguity, lack of participation in decision making, responsibility for subordinates,

- bad relations at work (with superiors, colleagues, subordinates and difficulty with delegation of responsibility),

- resulting from the organisational structure of the enterprise and the atmosphere in the organisation (limited liability, a staff policy),

- related to professional development (too fast or too slow advancement, unsatisfied ambitions, a lack of job security),

- non-organisational sources of stress (family problems, financial issues, life crises, conflicts between the enterprise's requirements and the needs of the family).

Whereas Ronald Burke and Astrid Richardsen (2000, pp. 191-209) list as many as eight groups of stressors, which include: physical environment, the organisational structure, the role of the organisation, interpersonal relations, characteristics of the task, career development, work-family conflict, modern stressors resulting from changes in the organisation and uncertainty of work (Burke, 1993, pp. 77-78).

It should be added, that particularly susceptible to stress are people: at a young age, with a short work practice, unmatched to performed duties because of inadequate suitability (e.g. visual acuity, decrease of hearing, limited manual capacity, delays of reflex response), abilities (e.g. in science, humanities or in artistic, technical, clerical activities), inadequate education or professional experience, with an innate sensitivity to stimuli, with large timidity and fear, very involved in professional affairs, aiming at a high level of aspirations and achievements, the need for control as well as impatience, rush and competition with others, at the older age, non-work problems, e.g. because of a divorce, the birth of a child diseases in the family. Therefore, these people will require temporarily an individual approach, as well as commissioning the obligations that will be adjusted to their current life situation.

It is known that people who are experiencing stress in the workplace are physically and mentally exhausted and suffer from both somatic and health ailments. The following issues should be mentioned:

a) mental health symptoms (e.g. apathy, forgetfulness, emotional tension or excessive seeking seclusion, the suppression of feelings, nightmares, anxiety, closing in oneself, a tendency to easily succumbing to dismay, annoyance, irritability, feelings of dissatisfaction, poor concentration , an excessive tendency to cry or escape or agitation, nervous laughter);

b) symptoms of physical health (e.g. stomach cramps, nausea, ulcers of the digestive system: stomach or duodenum, digestive disorders, chronic diarrhoea, pain in the muscles of the neck, shoulders, back, lumbosacral area of the spine, hypertension, stroke, coronary artery disease, myocardial infarction, cancer, depression, nervous disorders, infectious diseases, rheumatism, loss of appetite or excessive appetite, 
addiction, skin rashes, dizziness and headaches, migraines, floating knee, dilated pupils, insomnia, sleep disturbances, sweating, damp or cold hands, chronic fatigue, fainting, rapid and shallow breathing, dry throat, stuttering, speech disorder);

c) organisational symptoms (e.g. the decline in efficiency and productivity, resistance against changes and new tasks, unwillingness to work, simulation of the tasks - the so-called occupational burnout, an increase in absenteeism, the need to organise substitutions and overtime - overload of other workers, accidents at work, making unintentional mistakes and errors, avoiding: regulations and safety rules, or the commands of superiors, conflicts with co-workers and superiors, a lack of trust in superiors and co-workers, the image of an unfriendly enterprise, resignation from work).

These symptoms, in the case of chronic and undiminished stress in the organisation, can cause losses, increasing the cost of the enterprise. Misleading decisions made in a hurry, dissatisfied customers, a decrease in efficiency and productivity at work, costs of accidents at work and related to absenteeism of the employees affected by stress: substitutions, selections, recruitment, training and professional preparation of new employees - these are the examples of costs caused by unnecessary stress in the workplace.

In Polish organisations, employees are very stressed. This is confirmed by the results of the study presented in "The Workforce View in Europe 2017" carried out by the company ADP (ADP, 2017), providing professional services in the area of human resources and payroll. The results of the study show that $22 \%$ of Polish workers declare that they experience stress in the workplace every day. This is the largest group of stressed workers as compared to other studied countries (France, Germany, Italy, the Netherlands, Spain, Switzerland and the United Kingdom). In Spain, where workers are the least stressed at work, only 10\% experience daily stress in the organisation. It should be added that in Poland nearly half of the respondents (46\%) declare that they often or very often experience stress at work. The most stressogenic conditions are observed in the sectors of retail sale and recreation and health centres, where one in five people ( $19 \%$ and $20 \%$, respectively) says that stress is a problem. While the least annoyed at work are those employed in the sector of information technology and telecommunication, where only $11 \%$ of employees are stressed every day. Polish women experience strong stress more often than men $-20 \%$ of the Polish women claim that this is a daily phenomenon (a similar opinion is expressed by $15 \%$ of men). Polish workers experience stress less with age. People over the age of 55 experience stress the least. $39 \%$ of respondents in this age group claim that they never experience stress at work, which may be associated with greater experience or a reduced dimension of working hours and duties because of approaching retirement.

\section{Conclusions}

Occupational stress is definitely a problem of both scientific and social nature. From a scientific point of view it may be disappointing that despite many years of intensive research, a single, universal theory of stress has not been developed yet. However, the usefulness of one, general model of occupational stress can certainly be questioned, because the requirements of work in the organisation (stressors) undergo constant rapid transformations caused by social changes.

A certain level of stress is a normal phenomenon in the workplace and it is natural that the workers periodically experience it. However, if the stress becomes a regular phenomenon or reaches excessive levels, it can affect the performance of the employee, his/her satisfaction and well-being, as well as it can lower the involvement of employees and, consequently, force them to resign from work. 
Counteracting the stress at work is not the easiest and in no way it is able to guarantee $100 \%$ efficiency, but with the joint action of the organization's management team, trade unions, employees, doctors, health and safety services and other experts, stress in the work of the organization's employees can be significantly reduced, when activities are carried out together. The trade union organisation carries out in this way its most important duty to defend the rights and interests of workers. The employer, on the other hand, fulfils the obligation to provide employees safe and secure hygienic conditions of employment free from stress, takes care of an increase in the involvement of workers and their motivation to work. Decreasing sickness absences minimise the financial burden of both the employer and the insurance institutions.

In conclusion, it should be noted, that for many people, work is a very important part of life. For this reason, the huge (human) costs of occupational stress should be taken into account when decisions about work and health of workers in the organisation are made.

\section{References}

ADP (2017). The Workforce View in Europe 2017. Retrieved from: www.adp.pl/assets/vfs/Family-29/Workforce-View/PL-WorkforceViewWP-2017-VF.pdf.

Burke, R.J., Richardsen, A.M. (2000). Organizational-level interventions designed to reduce occupational stressors. In: P. Dewe, M. Leiter, T. Cox (eds.), Coping, Health and Organizations (pp. 191-209). London: Taylor \& Francis.

Burke, R.J. (1993). Organizational-level interventions to reduce occupational stressors. Work and Stress, 1, 77-78.

Cieślak, R., Widerszal-Bazyl, M. (2000). Psychospołeczne warunki pracy. Podręcznik do kwestionariusza. Warszawa: CIOP.

Cooper, C.L., Marshall, J. (1987). Źródła stresu w pracy kierowniczej i umysłowej. In: C.L. Cooper, R. Payne (eds.), Stres w pracy (pp. 123-164). Warszawa: PWN.

Grochmal, S. (1992). Stres, nasz wróg czy sprzymierzeniec? Wrocław: Zakład Narodowy im. Ossolińskich. Wydawnictwo PAN.

Karasek, R., Theorell, T. (1990). Healthy work. Stress, productivity and the reconstruction of working life. New York: Basic Book.

Kędzia, B., Kowalewski, S. (2002). O zagrożeniach i ryzyku. ATEST - Ochrona Pracy, 5, 46.

Kopaliński, W. (1971). Słownik wyrazów obcych i zwrotów obcojęzycznych. Warszawa: Wiedza Powszechna.

Lazarus, R.S. (1986). Paradygmat stresu i radzenia sobie. Nowiny Psychologiczne, 3-4, 1-39.

Orlak, K. (2008). Stres jako element ryzyka zawodowego. Praca i zdrowie, 3, 46.

PWN (2018). Encyklopedia PWN. Retrieved from: https://encyklopedia.pwn.pl/haslo/stres;3980346.html.

PWN (2018a). Słownik języka polskiego. Retrieved from: https://sjp.pwn.pl/sjp/stres;2524585.html.

Selye, H. (1960). Stres życia. Warszawa: Państwowy Zakład Wydawnictw Lekarskich.

Selye, H. (1977). Stres okiełznany. Seria: Plus minus nieskończoność. Warszawa: PIW.

The American Heritage Dictionary of the English Language (2016). Editors of the American Heritage Dictionaries. Retrieved from: https://www.ahdictionary.com/word/search.html?q=stress.

Widerszal-Bazyl, M. (2005). Stres psychospołeczny w pracy - pojęcie, źródła i konsekwencje, różnice indywidualne, prewencja. In: D. Koradecka (ed.), Nauka o pracy - bezpieczeństwo, higiena, ergonomia (chapter 5). Warszawa: ClOP.

Cite this article aS:. Drela, K. (2018). Selected problems of occupational stress in the organization. European Journal of Service Management, 4 (28/1), 95-102. DOI: 10.18276/ejsm.2018.28/1-12. 